University of Nebraska - Lincoln

DigitalCommons@University of Nebraska - Lincoln

Educational Psychology Papers and

Publications

Educational Psychology, Department of

2007

\title{
Us and Them: Identity and Genocide
}

David Moshman

University of Nebraska-Lincoln, dmoshman1@unl.edu

Follow this and additional works at: https://digitalcommons.unl.edu/edpsychpapers

Part of the Educational Psychology Commons

Moshman, David, "Us and Them: Identity and Genocide" (2007). Educational Psychology Papers and Publications. 87.

https://digitalcommons.unl.edu/edpsychpapers/87

This Article is brought to you for free and open access by the Educational Psychology, Department of at DigitalCommons@University of Nebraska - Lincoln. It has been accepted for inclusion in Educational Psychology Papers and Publications by an authorized administrator of DigitalCommons@University of Nebraska - Lincoln. 


\title{
Us and Them: Identity and Genocide
}

\author{
David Moshman \\ Department of Educational Psychology, University of Nebraska-Lincoln \\ Lincoln, Nebraska, USA
}

Genocide is commonly deemed to be either inexplicable or the result of special hatreds. I argue instead that genocide is an extreme result of normal identity processes. Four overlapping phases are proposed. (1) Dichotomization elevates one dimension of identity over others and, within that dimension, sharply distinguishes two categories: us and them. This may lead to (2) dehumanization, in which "they" come to be seen not just as different from "us" but as outside the human universe of moral obligation. (3) Destruction may result, accompanied and followed by processes of (4) denial that enable the perpetrators to maintain their moral self-conceptions. These phases are illustrated with examples from the Holocaust, the 1994 genocide in Rwanda, the Latin American dirty wars of the 1970s and 1980s, and the European conquest of the Americas.

$$
\begin{aligned}
& \text { Us ... } \\
& \quad \ldots \text { and them } \\
& \text { And after all we're only ordinary men } \\
& \text { Me ... } \\
& \quad \ldots \text { and you }
\end{aligned}
$$

God only knows it's not what we would choose to do

—Pink Floyd, The Dark Side of the Moon, 1973

Earlier versions of this article were presented at the June 2005 meeting of the Jean Piaget Society in Vancouver, British Columbia; in an October 2005 talk at Webster University in St. Louis, Missouri; in a November 2006 talk to Nebraska Citizens for Science in Lincoln, Nebraska; and as the keynote address at the November 2006 UNL College of Education and Human Sciences Student Research Conference, also in Lincoln. I am grateful to session organizer and discussant Michael Chandler for his thoughtful comments following the presentation at the Piaget Society and to Michael Hulsizer, Clay Naff, and Margaret Latta, respectively, for organizing the three subsequent presentations.

Address correspondence to David Moshman, Department of Educational Psychology, University of Nebraska-Lincoln, Lincoln, NE 68588-0345. E-mail: dmoshman1 @unl.edu 
If you knew who I was and who you were, you would not have killed me.

- Sign outside the Nyamata, Rwanda, Catholic Church, in which 10,000 people were killed on a single day in 1994 (Packer, 2002, p. 140).

Genocides are perpetrated by individuals acting collectively on behalf of what they perceive to be their own group against what they perceive to be a different group. At the heart of any genocide, then, are individuals who see themselves in ways that enable them to act collectively on behalf of their own group against another. At the heart of any genocide, in other words, is identity.

In attributing genocide to identity I do not mean to suggest that identity necessarily leads to genocide or that no other concepts are relevant to explaining genocide. I do suggest, however, that the concept of identity is crucial to any explanation of genocide. In this article, looking at genocide through the lens of identity, I propose that genocide can be understood as a process consisting of four overlapping phases: dichotomization, dehumanization, destruction, and denial. I address each of these in turn after some preliminary comments on genocide and identity.

\section{GENOCIDE AND IDENTITY}

By genocide, I mean an act or process of destruction aimed at an abstractly defined group of people. There may be many perpetrators but their actions must be sufficiently coordinated to constitute a singular act or process. The genocidal process may include deliberate acts of mass killing, but it may also consist, entirely or in part, of other actions undermining the biological, social, or cultural integrity of the victim group. The acts of destruction may be aimed at individuals, but the individuals are targeted on the basis of their actual or perceived association with a national, ethnic, racial, religious, political, socioeconomic, or other abstractly defined group. The group must be deliberately targeted, but the process may be deemed genocidal even if the motives of the perpetrators are complex and multifaceted, even if their perceptions of the victim group are wildly inaccurate, and even if the extent of destruction is less than total.

This definition is rooted in the original conception of genocide proposed by Raphael Lemkin (1944) and elaborated in a 1946 Resolution of the United Nations General Assembly (Churchill, 1997; Moshman, in press). Although the 1948 United Nations Genocide Convention is definitive for legal purposes, it is generally seen by genocide scholars as seriously flawed (for critiques and alternatives, see Chalk \& Jonassohn, 1990; Charny, 1994; Churchill, 1997; Fein, 1993; Moshman, 2001, in press; Totten, Parsons, \& Hitchcock, 2002). The present analysis of the role of identity in genocide does not hinge on details of definition but it does assume a general conception of genocide as group destruction. 
How, then, shall we explain genocide? For the most part, I suggest, we do not want to explain it at all. What we want, especially in the most obvious and gruesome cases, is to condemn the perpetrators and remind ourselves how different "we" are from "them." We resist even trying to understand why the perpetrators did what they did because we fear this may make it more difficult to condemn them. Such understanding may even suggest that we, under the same circumstances, would have done the same. Instead of seeking to explain, then, we take refuge in the mystification that genocide defies explanation. We condemn its perpetrators and sympathize with its victims, but assume that we can never understand it. Genocides, we insist, are unique evils that rend the fabric of history, black holes in the space-time of human experience from which no meaning can ever escape. Genocide is literally incomprehensible, we would like to believe, at least for good people like us.

This reaction is psychologically understandable but scientifically unhelpful. A guiding assumption of any social science is that human behavior-good, bad, right, or wrong - can, at least to some extent, be explained. The role of psychology, sociology, anthropology, and other social sciences is to seek such explanations. Thus the scientific study of genocide must assume that genocides can and should be explained. This does not preclude labeling and condemning particular acts, events, or persons as evil, but it reminds us that neither labels nor condemnations are explanations. As scientists, it is explanations we seek.

Perhaps the standard psychological explanation of genocide is that it is a crime of hate. In contrast to simply characterizing genocide as evil, to attribute it to hate is to hypothesize a cause. To see genocide as a crime of hate is to refer to a genuine and relevant psychological phenomenon. People do hate, and this undoubtedly plays a role in genocide (Sternberg, 2005). We should be wary, however, of easy suppositions that perpetrators of genocide are driven by hate. In a recent series of case studies (Moshman, 2005b), I looked for hatred in connection with the 1994 genocide in Rwanda, the Nazi death camp Treblinka, disappearances in Argentina, a dirty war massacre in El Salvador, and the 1890 massacre at Wounded Knee. One might think these were the right kinds of places to look, but in fact hatred turned out to be surprisingly elusive. There was less hate than I expected and strong evidence for a variety of alternative motivations.

The complexity of genocidal motivation, however, is no reason to abandon the search for explanation. On the contrary, explanation is not only possible but has to some extent already been achieved. There is, it appears, an emerging consensus among genocide scholars that genocides and mass killings are mostly perpetrated by ordinary people playing social roles in groups, institutions, and practices to which they are politically, religiously, philosophically, ideologically, morally, professionally, economically, and/or personally committed (Arendt, 1963/1994; Ashmore, Jussim, Wilder, \& Heppen, 2001; Browning, 1998, 2004; Maybury-Lewis, 2002; Moshman, 2004a, 2004b; Osiel, 2001; Sereny, 1983; 
Staub, 1989, 2001, 2003; Totten et al., 2002; Waller, 2002; Weitz, 2003; Woolf \& Hulsizer, 2005). There may be a relatively small number of individuals who play disproportionate roles in the turn toward destruction (Valentino, 2004), but they act on behalf of the group.

Genocide, in other words, is not so much a crime of hate as a crime of identity. By identity, I mean a conception of oneself in one's social context that is sufficiently organized, explanatory, and conscious to be deemed "an explicit theory of oneself as a person" (Moshman, 2005a, p. 89; see also Moshman, 2004b). This conceptualization of identity is rooted in the neo-Eriksonian paradigm of personal identity (Moshman, 2005a), but recognizes that to see oneself as a person is to see oneself in relation to others and in relation to various groups. Correspondingly, to see oneself in relation to a variety of people and groups is to see oneself as an individual with a unique pattern of social relationships, affiliations, roles, and commitments. Thus social identity requires, and can be rooted in, a socially plausible conception of personal identity. As an explanatory concept, identity has the advantage that it cuts across levels of explanation and across the social sciences (Appiah, 2005; Ashmore, Deaux, \& McLaughlin-Volpe, 2004; Côté, 2006; Postmes \& Jetten, 2006). Through the multidisciplinary lens of identity, we can understand genocide as an act of group against group without relinquishing our sense that individuals are, and must be, causally and morally responsible for their own genocidal actions.

What, then, do we see when we look at genocide as a phenomenon of identity? The path toward genocide, I suggest, manifests a process in which identity options are drastically narrowed to two, and then to one.

\section{DICHOTOMIZATION}

People can define themselves with respect to many dimensions - tribe, race, religion, ethnicity, gender, sexuality, nationality, ideology, political commitments, moral commitments, professional roles, family roles, social relations, personal qualities, long-term goals, etc. Not every possible dimension of identity is relevant to everyone, but people generally define themselves on the basis of multiple affiliations and commitments, some of which are deemed more central than others. As a result, everyone has a unique identity but every identity potentially overlaps with virtually every other in one or more ways.

Dichotomization involves the construction of social and cultural understandings that render some potential dimensions of identity so salient or even mandatory that others become peripheral. Increasing numbers of people see themselves and others as defined on the basis of a small number of dimensions. At the limit, one dimension is highlighted over all others as what does or should define who everybody is, and that dimension is reduced to two categories (Brewer, 2001; Kelman, 2001; Maalouf, 
2001; Sen, 2006; Stanton, 2004). There are always some who resist dichotomization by continuing to classify themselves and others along multiple dimensions, thus allowing more diverse interconnections and lines of communication. To the extent that dichotomization prevails, however, alternative identities are increasingly marginalized or disparaged. In the end, those who are not us are them.

Consider the 1994 genocide in Rwanda (Dallaire, 2003; Des Forges, 1999; Fujii, 2004; Hatzfeld, 2005; Mamdani, 2001; Melvern, 2000; Mironko, 2004; Moshman, 2004b; Power, 2002; Stanton, 2004). In precolonial Rwanda, there was a fluid distinction between Hutu and Tutsi based on a combination of ancestry and socioeconomic status, including ownership of cattle. This distinction, unique to Rwanda and Burundi, was misleadingly assimilated by the Western media to more familiar conceptions of tribe and ethnicity. Contrary to the resulting portrayals, the Hutu and Tutsi were not tribes or ethnic groups. Rather, they lived among each other, intermarried, shared religious beliefs, and were integral parts of a single society-Rwanda. The Hutu/Tutsi distinction, though real and important, was but one of many dimensions along which Rwandans classified and differentiated themselves and others.

During the period of colonial rule in the early 20th century, Belgium reified and exploited the Hutu/Tutsi distinction to control the country by enabling the Tutsi, operating within Belgian parameters, to solidify and enhance their traditional domination of the Hutu. Mandatory identity cards classified everyone as Hutu or Tutsi (or Twa, constituting under 1\%), thus elevating this dimension of diversity above all others and officially dichotomizing the population. With independence in the early 1960s, the majority Hutu took power. Many of them believed that their time had rightly come after centuries of Tutsi domination. Correspondingly, many Tutsi believed that authority in Rwanda had always rightly been theirs, and should be regained. Thus the Hutu/Tutsi distinction retained its centrality in postcolonial Rwanda. Despite explicit warnings that the identity cards could facilitate geno cide — which they later did — efforts to eliminate them were unsuccessful.

Prior to the genocide, Rwandans could see themselves as Rwandan, and/or as Hutu or Tutsi, and/or as affiliated with or committed to various religions, professions, political parties, activities, ideologies, etc. Two Rwandans chosen at random would likely have had in common that they were both Catholic (a colonial legacy) and speakers of Kinyarwanda (the precolonial language) and were likely to have other potential aspects of identity in common as well. The pathway to 1994 involved a narrowing of options. As Hutu Power ideology spread through radio and other means, Rwandans increasingly came to see themselves and others as, first and foremost, Hutu or Tutsi, with other identifications and potential connections distinctly secondary. As the middle ground collapsed, you had to stand on our side or theirs. And in the early days of the genocide, the victims included tens of thousands of moderate Hutu who were deemed by Hutu Power to have betrayed their Hutu identity. 
The path to the Holocaust similarly involved an ongoing process of dichotomization. Jews in early 20th century Germany generally saw themselves, and were generally seen, as Germans with Jewish beliefs and/or ancestry who varied among themselves in most of the ways other Germans also varied. Highly assimilated, they were generally seen as having individual identities that included, but were not defined by, their Jewishness. As Nazi ideology prevailed, however, Jewish Germans became a more distinct group. Before long, they were no longer even seen as Jewish Germans but rather as German Jews. They had been part of German society, with rights under the German state, but they had never been, and could not be, part of the racially defined German nation. They were Jews. They were part of the Jewish nation, along with the millions of Polish, Russian, and other Eastern European Jews who came under Nazi control in the early years of the Second World War. Thus Germans who were Jewish among many other things became Jewish Germans in a more fundamental sense, and then German Jews, and finally just Jews. Jewishness became a defining quality regardless of nationality, beliefs, profession, political commitments, etc. (Browning, 2004).

Argentineans also vary along many dimensions, but during the late 1970s, in what came to be called the "dirty war," the political dimension became salient and ultimately dominant. Not only did people come to be defined by their politics, but politics was reduced to just two categories, patriotic or subversive (Arditti, 1999; Bouvard, 1994; Fisher, 1989; Osiel, 2001). Parallel processes of dichotomization took place at about the same time throughout Latin America. In El Salvador, Guatemala, and otherCentral American countries, entire villages and regions were categorized as patriotic or subversive (Archdiocese of Guatemala, 1999; Danner, 1994; Sanford, 2003). Villages perceived as supporting insurgents were in a different category than villages perceived as supporting the military governments. In the "red zones," moreover, all villages, and thus all people, were assumed to be supportive of the insurgents. If you were living in a red zone, you were one of them, not one of us.

In cases of first contact between different groups, dichotomization is not a process but a starting point. The initial encounters of indigenous peoples and European nations in the Americas, for example, were encounters between pre-existing groups. In cases such as these, each group is faced, perhaps quite suddenly, with the existence of an unexpected other. This may generate questions that otherwise arise only in the course of what is often an extended process of dichotomization. Questions about who "they" are, moreover, entail questions about who "we" are, and the answers to those questions guide us in determining what to do about "them."

\section{DEHUMANIZATION}

To dichotomize is not necessarily to elevate one identity over another. One can believe, for example, that people are most fundamentally defined by their racial an- 
cestry without believing that any race is superior to any other. Alternatively, one can believe that people are most fundamentally defined by their religious commitments without believing that any particular religious commitment is the right one. As should be clear from these examples, however, people often have strong preferences for some identities over others, especially with regard to what they consider the most fundamental set of categories and commitments. In some cases, identities deemed inferior may be actively stigmatized or, in the extreme, dehumanized. In dehumanization, those deemed to be members of the out-group are denied the status of persons. Rather than being seen as members of a human community with individual identities of their own, they are construed as elements of a subhuman, nonhuman, or antihuman collective (Woolf \& Hulsizer, 2005).

In the period leading up to the 1994 genocide in Rwanda, for example, the Tutsi were persistently portrayed in Hutu Power propaganda as inyenzi, cockroaches. Not only were they a group distinct from the Hutu, regardless of their individual identity commitments, but they were increasingly construed as a group distinct from humanity, not capable of meaningful individual identities. Thus the killing of Tutsi was no more a violation of individual rights than the killing of cockroaches or, in another metaphor also popularized by Hutu Power, the pulling of weeds. On the contrary, given the threat allegedly posed by the Tutsi to the future of Rwanda, their elimination was deemed a moral imperative.

Similarly, a key aspect of the path to the Holocaust was the relentless dehumanization of Jews (Stannard, 1998, pp. 182-183). As Germans with Jewish ancestry were increasingly seen as Jews above all else, they came to be seen as less than fully German, and ultimately as less than fully human, part of a nonhuman mass of Jews. For Hitler, Jews were antihuman. Weitz (2003) provides a concise summary of the biological metaphors of Hitler's Mein Kampf: "Jews were the maggots feeding on a rotting corpse, the parasites that had to be surgically removed, the sexual predators preying on German women, a spider that sucks people's blood, a plague worse than the Black Death, the sponger who spreads like a noxious bacillus and then kills his host" (p. 106). Franz Stangl, in contrast, did not share Hitler's animosity toward Jews, but Stangl's blander dehumanizations were sufficient to enable him to serve as commandant of the death camp Treblinka (Moshman, 2005b; Sereny, 1983). To him the Jews were more like "cattle," a mindless herd, making its way toward the slaughterhouse where it would be transformed into "a mass of rotting flesh" that "had nothing to do with humanity." The Jews were "cargo" to be transported and their bodies were "garbage" to be disposed of. "I rarely saw them as individuals," he explained. "It was always a huge mass." (Sereny, 1983, p. 201)

In Argentina in the late 1970s, individuals who questioned the status quo or worked with the poor ceased, at least from the perspective of the military government, to be Argentines with leftist beliefs and/or commitments to social justice. Now they were deemed subversives, threats to Argentina and to all true Argentines. They were not simply different from other members of the diverse human 
community. They were outside that community and in opposition to it. As General Ramon Camps explained, "It wasn't people that disappeared, but subversives" (quoted in Fisher, 1989, p. 102). The same process of dehumanization operated in Chile and elsewhere during the Latin American dirty wars.

In Central America, as noted above, entire villages and regions were deemed subversive. The beliefs and commitments of particular persons were beside the point. Not even the complete absence of any political consciousness, as in the case of young children, was relevant. The villagers were perceived as the human sea in which the guerrilla fish swam, and without which they could not operate. Inhabitants of subversive villages or red zones were part of a subversive collective, not individuals with identities of their own. They were a threat to the human and moral universe, not part of it. In Guatemala, Mayans who survived the destruction of their villages ended up desperately seeking food, water, and shelter in the mountains, where, increasingly forced to live like animals, they were hunted down as such. In operations known as "hunting the deer," multiple platoons would surround a large forested area into which soldiers would shoot from three sides. Terrified Mayans would flee in the only remaining direction and run into military forces ready to finish the kill (Sanford, 2003, p. 160).

In the Spanish conquest of Hispaniola, the rest of the Caribbean, and then the mainland, the human status of the "Indians" was always a major question. Were they people? Did they have souls? Or were they just part of the flora and fauna of the New World? Opinions differed on these questions but perhaps the mainstream view was that Indians were in a category of their own, or one they shared with black Africans: They were "savages," more human than any animal but not part of the "civilized" world. The ubiquitous rapes of female Indians, in this regard, are telling (Stannard, 1992, pp. 84-85). The exceptional brutality of these rapes tempts the observation that the Spanish men treated their victims like animals, but this is not true. They did not rape or brutalize female animals. But neither did the Spanish men treat female Indians like Spanish women. Spanish women were not systematically raped with impunity and ideological approval. Whatever sex discrimination Spanish women suffered, they were nevertheless Spanish. They were females within a human community, and thus women. From the Spanish point of view, female Indians were not women; but neither were they animals. They could be abused in a way no animal could be abused, but their violation was of no moral consequence.

The language of dehumanization is extensive. Members of dehumanized groups have been variously portrayed and seen as weeds, rats, vermin, dogs, cows, viruses, maggots, microbes, parasites, plague, pests, snakes, spiders, lice, locusts, cockroaches, cancerous cells, and malignant tumors. Less biologically, they have been portrayed and seen as heretics, heathens, infidels, barbarians, savages, subversives, or terrorists. And then there are the many specialized dehumanizing labels and stereotypes for specific groups around the world. What all of these con- 
ceptualizations have in common is that they restrict the moral universe to "us." "We" are moral individuals who acknowledge and respect our obligations to each other. "They" are not just different but are not fully persons at all and thus not among those to whom our moral obligations extend:

- There can be no moral obligation to cockroaches, whether they are literally insects or the equally contemptible Tutsi.

- We have no moral obligation to the welfare of a cancer, maggot, or parasite eating away at the body politic.

- We need not respect the human rights of lice infesting our hair, weeds overwhelming our gardens, or vermin invading our homes.

- We cannot share a common moral ground with heretics, heathens, or infidels who deny (what we see as) the very basis for morality.

- There is no moral limit on what can be done to (those who have been labeled) savages, subversives, or terrorists.

Dehumanization reinforces and extends dichotomization. If "they" are something other than human, then they cannot share interests, values, or commitments with "us." Our own identities are diverse enough to affirm our individual humanity but converge with regard to whatever it is we see as the fundamental difference between any of us and any of them. That difference is so fundamental, in fact, that our moral obligations to others, which are of course obligations to other people, are not obligations to "them."

Thus we draw a moral circle around what we construe to be "us," with a shared understanding of who lies within that circle, and who lies outside it (Brewer, 2001; Staub, 2001; Woolf \& Hulsizer, 2005). Our moral obligations are obligations to each other and to our collective identity. This need not lead to action against "them," provided we perceive them as keeping in their place and meeting what we perceive as our legitimate expectations. But human groups often get in each other's way and fail to meet each other's expectations. Groups often perceive each other as threatening, whether the threat is genuine or not. Under these circumstances we may come to feel morally obligated to join together against those who threaten or impede us, and do what must be done. If we and they are evenly matched, the result may be war. If not, it may be genocide.

\section{DESTRUCTION}

Consider genocide in microcosm: the 1981 massacre at El Mozote by the Atlacatl Battalion during the dirty war in El Salvador (Danner, 1994; Moshman, 2004a). An elite unit of the Salvadoran army trained by the United States, the Atlacatl Battalion specialized in genocidal massacres. Its mode of operation was to take con- 
trol of villages and kill everyone. On December 10, 1981, the soldiers of the Atlacatl arrived in El Mozote, a mountain village of several hundred people. They immediately ordered everyone to come out of their homes and lie face down in the street. They then proceeded to kick and beat them, taking jewelry and crucifixes and demanding information about guerrillas and weapons. Hours later, long after dark, they sent the villagers back to their homes for the night. Before dawn the next morning they ordered them out to the Plaza and kept them standing for hours. They separated the men and eventually herded them into the church. There they were bound, blindfolded, brutally interrogated, and finally decapitated or shot. They took the women and children to a nearby house, from which the younger women and older girls were later dragged to be raped and killed. Then they took the older women in groups to another house, where they were shot. Later groups, seeing the piles of bloody corpses through the doorway, had to be forced inside, screaming and begging. Finally, the soldiers of the Atlacatl turned their attention to the hysterical children, smashing their heads with the butts of rifles and slashing their throats with machetes. Then they herded those left into the tiny church sacristy and shot them all to death.

This is the kind of behavior that leads us to see genocides as evils beyond explanation, and the perpetrators of genocide as inhuman, as if they had just arrived from another planet. If we want to explain genocidal behavior, however, we must keep reminding ourselves, as often as necessary, that the perpetrators of genocide are human, and that their behavior is human behavior.

What make genocidal massacres possible, I suggest, is a dichotomization of identities and a conception of the other as less than human. In the case of the Atlacatl Battalion, the villagers were inhabitants of what was called the "red zone," where "subversives" operated. The political identities of individuals within the red zone, though diverse, were not relevant. All were part of a subversive mass that had to be eliminated, even the children. For the soldiers of the Atlacatl, moreover, this was a moral mission on behalf of their fellow Salvadorans and their nation: "We are warriors," they sang, "warriors all! We are going forth to kill a mountain of terrorists!" (Danner, 1994, p. 50).

Governmental forces with similar motives destroyed hundreds of villages in El Salvador, Guatemala, and elsewhere over the course of the dirty wars. In Guatemala, where the dirty war cost some 200,000 lives, the genocidal massacres specifically targeted Mayan villages (Sanford, 2003). Many Mayans engaged in activities deemed subversive, ranging from community organizing to human rights activism to material support for leftist guerrillas to active participation in violence. To be indigenous came to be associated with subversion, making Maya part of "them." The destruction of Mayan villages was thus an integral part of the dirty war.

The targeting of indigenous peoples by government forces, however, was not new. On the contrary, it had by this time been going on all over the Americas for 
nearly five centuries. On Hispaniola, where Columbus established Spain's first military outpost in the New World, his men exploited and brutalized the initially friendly natives until they resisted. In response, as described by the Catholic missionary Bartolomé de Las Casas (1552/1992),

\begin{abstract}
the Christians, with their horses and swords and pikes began to carry out massacres and strange cruelties against them. They attacked the towns and spared neither the children nor the aged nor pregnant women nor women in childbed, not only stabbing them and dismembering them but cutting them to pieces as if dealing with sheep in the slaughter house. They laid bets as to who, with one stroke of the sword, could split a man in two or could cut off his head or spill out his entrails with a single stroke of the pike. They took infants from their mothers' breasts, snatching them by the legs and pitching them headfirst against the crags or snatched them by the arms and threw them into the rivers, roaring with laughter and saying as the babies fell into the water, "Boil there, you offspring of the devil!" (pp. 33-34).
\end{abstract}

Across Hispaniola, which now comprises Haiti and the Dominican Republic, Taino villages were burned and their way of life destroyed. Many of those who were not massacred outright were enslaved and worked to death, or died of starvation, or both. Many were felled in massive epidemics by European diseases to which they had no immunity. Many were so devastated psychologically that they refused to procreate. Some killed their newborn children. From a 1492 population estimated to be in the millions, the number of Taino on Hispaniola declined to zero by the mid-1500s (Churchill, 1997; Rouse, 1992; Stannard, 1992).

The destruction of natives expanded concentrically far beyond Hispaniola in the ensuing decades and centuries, and was widely deemed necessary and justified not only by the Spanish but by other European powers as well. The English philosopher John Locke, in his Two Treatises on Civil Government, explained that rebellious natives had "declared war against all mankind, and therefore may be destroyed as a lion or tiger, one of those wild savage beasts with whom men can have no society or security" (quoted in McDonnell \& Moses, 2005, p. 513).

Group destruction can also be accomplished through nonlethal social practices. A good example is the operation of Indian boarding schools in the United States and Canada from the late 19th century to the mid-20th century (Adams, 1995; Churchill, 2004; Lomawaima, 1994). Attended by children from dozens of tribes, the residential schools were designed to eliminate Indian cultures by severing the link between generations. Isolated from their families and communities, students were issued new clothes and new names. Boys had their long hair cut, often to their great dismay, and all children received clothing suitable for their gender in "civilized" society. Indian names, usually rich with cultural meanings, were replaced with names deemed more appropriate for students' future lives. Luther Standing Bear (quoted in Adams, 1995, p. 111) recalled that days after his arrival at Carlisle 
Indian School—-before the students could even speak, much less read, English - the interpreter said to his group, "Do you see all these marks on the blackboard? Well, each word is a white man's name. They are going to give each one of you one of these names by which you will hereafter be known." Each boy was required to touch one of the names with a long pointer. The chosen name was written out and attached to the back of his shirt. "When my turn came, I took the pointer and acted as if I were about to touch an enemy. Soon we all had the names of white men sewed on our backs."

Students were expected to learn English not as a second language to supplement their first but as a replacement for it. Accordingly they were strictly forbidden to speak their native languages. Teacher Minnie Jenkins recalled an occasion on which she laid 35 kindergartners across tables "like little sardines" and spanked them all for speaking their native Mohave (quoted in Adams, 1995, p. 141). As children learned English, the curriculum expanded. Christian beliefs and middle class virtues were fundamental. History lessons highlighted the progress of civilization in the Americas since 1492 and their good fortune to be part of that. In addition, boys were trained in agricultural and industrial skills, and girls in domestic skills, to enable them to function in the society into which they were being assimilated.

The success of the Indian schools was proudly illustrated in widely distributed before-and-after photos that showed young savages transformed into upstanding Americans. As Reverend J. A. Lippincott proclaimed to students at a commencement at Carlisle Indian School, "The Indian is dead in you. Let all that is Indian within you die!... You cannot become truly American citizens, industrious, intelligent, cultured, civilized until the Indian within you is dead" (quoted in Adams, 1995, p. 274, emphasis in original). "Kill the Indian, save the man" was the motto of the residential school system. No one would literally be killed - in principle — but "Indians" would cease to exist. Thus children were "saved." What was killed was the subhuman identity that would otherwise have been theirs.

Destruction has many forms. In Rwanda, some 800,000 people out of a population of 8 million were killed, mostly with machetes and other such implements, in 100 days. Hitler killed many millions, and Stalin and Mao even more (Rummel, 1994). But the residential schools remind us that more subtle genocidal processes, aimed across generations, can be equally effective in destroying cultures, quietly extinguishing entire ways of life.

\section{DENIAL}

Denial accompanies and follows genocide so routinely as to constitute its normative final phase (Woolf \& Hulsizer, 2005). Ongoing dehumanization of our victims 
is one method of not facing the genocidal nature of what we have done. Other methods of genocide denial range from brute rejection of the facts to more subtle means such as not investigating what we don't want to know; selectively remembering what we already know; gerrymandering the definition of genocide to exclude our own actions; recontextualizing historical circumstances to render our actions normal, understandable, or inevitable; and educating our children with history textbooks devised primarily for the purpose of instilling patriotism (Chomsky, 1989; Cohen, 2001; Hulsizer, Munro, Fagerlin, \& Taylor, 2004; Loewen, 1995; Moshman, 2001, 2004a).

In many cases, it is precisely our own identity as moral agent that forces us to deny the identities of those we destroy. The concept of moral identity has served, especially in developmental psychology, to explain how moral motivation may be stronger if (and to the extent that) being moral is a core identity commitment (Bergman, 2004; Moshman, 2005a). But once we have done whatever we have done, for whatever reason, our moral identities motivate us to deny or dispute evidence and interpretations that make us look immoral. In particular, because genocide is widely seen as the most terrible of all crimes, and because most of us see ourselves as moral agents within a moral community, we are highly motivated to deny that anything we or our group do or have done is genocidal (Hamblett, 2005; Moshman, 2001, 2004a).

In Argentina during the dirty war, especially in the late 1970s, students and young adults who had, or were perceived to have, leftist political commitments, in some cases simply because they worked with the poor, were kidnapped by government forces, tortured for months in hundreds of secret facilities around the country, and finally killed. Sometimes their bodies were tossed from cars onto dark streets. Often they were buried in secret graves. Many were sedated and dropped alive from airplanes into the Atlantic Ocean. Children kidnapped with their parents or born in prison, if not destroyed with the rest of their "subversive" family, were secretly placed with childless parents to be raised as proper Argentines and Catholics with due respect for "tradition, family, and property" (Arditti, 1999; Bouvard, 1994; Fisher, 1989; Moshman, 2005b; Osiel, 2001).

Parents of the disappeared had no knowledge of the fate of their children and were initially as isolated as they were devastated. In time, however, some came together, and before long there were weekly marches in Buenos Aires by those who came to be known as the Mothers of the Plaza de Mayo. Then the Grandmothers of the Plaza de Mayo organized to seek their grandchildren - the missing children of their missing children - arguing that only thus could the children of the disappeared reclaim their rightful identities. In response to all inquiries and demonstrations, the government insisted it knew nothing. The allegedly missing men, it was suggested, had left their families to join subversive groups. The women had gone off to become prostitutes. The alleged children did not exist. There was no missing group of people, claimed the government, no collective identity that had been targeted for destruction (Arditti, 
1999; Bouvard, 1994; Fisher, 1989; Mellibovsky, 1997; for a fictional account of ongoing denial sixty years later, see Moshman, 2006).

This pattern of elimination and denial, rooted in Nazi Germany's Nacht und Nebel (Night and Fog) program, became known as "disappearances." The victims were said to have been disappeared. To be disappeared is not to have something happen to you but to have something done to you. Tens of thousands of individuals were disappeared during the dirty war in Argentina, and tens of thousands more elsewhere in Latin America, including Guatemala, El Salvador, and Chile. The official view of the government was that the so-called disappeared had never existed, and thus there was nothing to explain.

Given the prevalence of denial, most genocides are, in a fundamental sense, collective disappearances. The hundreds of villages in Guatemala, El Salvador, and elsewhere that were eliminated in the dirty wars are long forgotten, especially in the United States (Archdiocese of Guatemala, 1999; Sanford, 2003). Through a fortuitous set of events, the massacre at El Mozote was reported on the front pages of the New York Times and the Washington Post in January 1982. Nevertheless, it was still successfully denied by the Reagan Administration in its request to Congress for continuing aid to the Salvadoran military (Danner, 1994; Moshman, 2004a). In part, the denial relied on a mentality of "don't ask, don't tell." The Administration knew less than it could have found out, reported less than it knew, and relied on Congress not to want more information. In addition, the denial involved misleading processes of contextualization. Although the Salvadoran government and its affiliated death squads were responsible for the overwhelming proportion of killings in El Salvador, including genocidal massacres such as that at El Mozote, the Administration presented governmental atrocities as if they were an expected, and declining, piece of a larger context of violence for which the government was mostly not responsible. Some members of Congress denounced the Administration's testimony as Orwellian, but Congress as an institution did not challenge administrative evidence and interpretations. And so, not only was El Mozote gone, but with it the knowledge that it had ever existed. The many other Central American communities destroyed in genocidal massacres are even less remembered. They have been disappeared from the face of the earth.

Preparation for subsequent genocide denial often begins while destruction is still in progress. A particularly systematic example of preparing for genocide denial is Operation Reinhard, arguably the core of the Holocaust (Arad, 1987). The Nazis considered it a secret of the highest order. In the three death camps of Operation Reinhard-Belzec, Sobibor, and Treblinka-more than 1.5 million Jews were gassed to death in less than two years. The cover-up, in preparation for future denials, included the burning of all the bodies. This was a change in policy, necessitating the exhumation for burning of hundreds of thousands of bodies that had earlier been buried. The annihilation of the Jews was seen by the Nazis as a necessary and noble undertaking, but one for which they, and future generations of Germans, might not wish 
to take responsibility. German moral identity had to be protected. Thus Operation Reinhard ended with a systematic effort to eliminate itself and its victims from history. In Treblinka, after the transports, gassings, and cremations had ceased, the last thirty Jewish slave laborers spent each night in freight cars on the railway spur until they were shot by three SS men in late November 1943, five at a time, each group cremating the corpses of the prior group. The final group was cremated by Ukrainian guards. Treblinka was then demolished, as were Belzec and Sobibor. At the site of each former death camp a small farm was created, and arrangements were made for each farm to be occupied by a former Ukrainian guard and his family.

Denial is also important to bystanders as a basis for not intervening. In the case of Rwanda, denial was a collaborative international effort led by the United States. At the time of the genocide, the United Nations had a peacekeeping force of several thousand soldiers in Rwanda under the command of Lieutenant-General Roméo Dallaire. Dallaire made a convincing case, fervently and repeatedly, that with a few thousand additional troops and an expanded mandate he could halt the genocide in its tracks. From the US point of view, however, Rwanda was a small central African country with no special resources and no strategic importance. With the "Black Hawk down" debacle in Somalia still fresh in mind, there was a bipartisan consensus that intervention in Rwanda was out of the question. But as a matter of American moral identity, not intervening in genocide was also unacceptable. After the Holocaust and the United Nations Genocide Convention, "never again" is seen as a moral imperative, and Americans, like most groups of people, see being moral as central to who they are. Thus it was critical to maintain that what was happening in Rwanda was civil war, not genocide. All evidence was interpreted accordingly. Use of "g-word" in public statements was eschewed. Acceding to American pressure, the United Nations not only failed to provide General Dallaire with the reinforcements and authority he requested, but instead withdrew most of his troops. Only after hundreds of thousands of Tutsi and tens of thousands of moderate Hutu had been killed, with the genocide nearly complete, did the US acknowledge that "acts of genocide" had taken place (Dallaire, 2003; Des Forges, 1999; Melvern, 2000; Power, 2002; Stanton, 2004).

Among Rwandans, however, the denial had only begun. It remains to this day — and will remain for years to come — a work in progress (Hatzfeld, 2005; Mamdani, 2001; Mironko, 2004). Although some perpetrators lie to protect themselves, most acknowledge the reality, scope, and genocidal intent of the killings in which they and their Hutu compatriots participated. Their memories, however, continue to reflect the dehumanizing conceptions that enabled their participation. They remember the genocide as a series of daily hunting expeditions, a group project in which they and their colleagues flushed Tutsi out of hiding, chased them, herded them, and finally slashed them to death with machetes. Many of the perpetrators continue to see this as "work" that, unfortunately, had to be done, given the existential threat posed by the Tutsi to the Hutu and Rwandan nation. Years later, 
however, outside the context of the hunt, it is more difficult to see the hunted as animals, and thus to justify the killing. Not only must perpetrators now decide what to tell to whom; they wrestle also, at the edge of consciousness, with recurring issues of what to acknowledge to themselves. "Even in your heart of hearts," said Ignace Rukiramacumu, who hunted and killed Tutsi daily for a period of weeks, "it is riskier to remember than to forget. Therefore I try to keep quiet with myself" (quoted in Hatzfeld, 2005, p. 163).

Finally, on a scale of denial far beyond anything yet discussed, the nations of the Americas remain virtually oblivious to their emergence from a series of genocides that were deliberately aimed at, and succeeded in eliminating, hundreds of indigenous cultures (Barkan, 2003; Churchill, 1997; Stannard, 1992). History, we assume, is a story of "progress." Seeing the rise of "civilization" in the replacement of "barbarian" cultures with our own, we fail to see destruction all around us. Instead, we speak of "vanishing" natives and cultures as if such vanishing were a natural process for which no one is responsible, least of all us. Notions of "manifest destiny" generate visions of history as the inevitable unfolding of what was always meant to be, obscuring the choices made by our predecessors and the options now available. In these and other ways the nations of the Americas and most of their citizens do not see what they do not want to know. Our national identities intertwine with our moral identities, and no one wants to identify with a nation founded in genocide.

But even if there are nations not founded in genocide, it is doubtful there are many without genocides in their history or without corresponding processes of genocide denial. Denial is often easy to spot when our enemies do it, but our pervasive self-deceptions are all too successful. Sometimes we lie, but for the most part we really do believe that they were less worthy than us; that they were a threat to us; that we were faced with exceptional circumstances, with an enemy like no other; that we intended no more harm than necessary; and that our crimes, if any, have been exaggerated. What we did is what had to be done, what anyone would have done. Even they must recognize that what happened is what had to happen. Perhaps there were some unfortunate incidents, but such excesses are inevitable, and we were not the only ones responsible. Now, in the name of peace, responsibility must be shared so we can all work together to achieve closure and move on. Whatever the truth of our complex and tragic history, the time has come to forgive, to join in reconciliation, to put the past behind us for the sake of the future.

Thus we forget - if we ever knew—what we do not want to know. Not seeing genocide is often a challenge, but human cognition is up to the task.

\section{CONCLUSION}

The concept of identity, I have suggested, helps us see the pathway to genocide, helps us understand how we come to do what we would not have thought possible, 
and helps account for the aftermath, in which we deny what we have done. Dynamics of identity initiate, guide, and extend the process of genocide. Dichotomization enables dehumanization, which in turn enables destruction, after which we maintain our moral identities through processes of denial.

As we have seen, however, these phases are substantially overlapping. They are not qualitatively distinct stages emerging in a stair-step progression. Dehumanization reinforces the initial dichotomization that, by constituting the other as different, makes dehumanization possible. Participation in destructive processes reinforces and enhances the dichotomization and dehumanization that enable and justify destruction. As we join in doing what we know should not be done to people, it becomes increasingly difficult to see our victims as people. Instead we see them in ways that make it easier to destroy them and, ultimately, to justify having done so. Thus dehumanization may accompany and follow destruction. Denial typically accompanies and cloaks destructive practices and then takes on a life of its own. Ongoing denial of what we have done - the denial that our victims ever even existed — extends the dehumanization and completes the destruction.

Dichotomization can be seen in many contemporary situations. In the case of Israel/Palestine, for example, the dichotomization is so severe that the inhabitants and former inhabitants of the geographical area in question cannot even be designated without two names separated by a slash, as if to represent two worlds that cannot be reconciled. "In a sense," wrote Rashid Khalidi (1997, p. 17), "each party to this conflict ... operates in a different dimension from the other, looking back to a different era of the past, and living in a different present, albeit in the very same place." Dichotomized identities generate divergent histories, which in turn generate divergent conceptualizations of the present conflict.

Dichotomization does not necessarily lead to genocide, but in strong forms it is cause for serious concern, especially when it is accompanied by dehumanization. Almost by definition, for example, those we label terrorists in the current "war on terror" are seen as a group not just different from us but utterly beyond human reason. The only way to deal with them is to destroy them. As in the case of the dirty wars, whose targets were also labeled terrorists, there is considerable ambiguity as to who is to be destroyed. But the moral logic seems clear. If those we destroy are terrorists, and terrorists can only be destroyed, then those we destroy can only be destroyed. We are doing what must be done.

It is not only our enemies, then, who slip easily into genocidal thinking. We all do. Does it help to know that? Is there anything we can do about it? More generally, what should we do about genocide? Does a conception of genocide as a crime of identity provide any real guidance? I think it does, but what it tells us is not always what we want to hear.

For one thing, a conception of genocide as a crime of identity reminds us that to understand genocide we must see the victims, and the acts of genocide, from the perspective of the perpetrator. This is not only an intellectual challenge but an emotional 
and moral challenge as well. To understand genocide, we must understand why the perpetrators did what they did, which means seeing the world from their point of view. And we must face the possibility that, if we are serious about this, their point of view may turn out to be more understandable than we wanted it to be.

Second, a conception of genocide as a crime of identity helps block our natural tendency to see ourselves and our groups as fundamentally different from the perpetrators of genocide. It reminds us that we all have what it takes to commit genocide: identities. It is easier to say this than to really believe it. We would rather think that genocide is committed by people who are uniquely evil or hateful. We must come to grips with the fact that genocides are committed — and denied—by people like us, whoever "we" may be. It is not only our enemies who should reflect on what they have done, and what they are doing.

Finally, a conception of genocide as a crime of identity makes it clear that there is no simple means to eliminate genocide. If genocide were rooted in hatred we could seek to eliminate hate, and we might at least manage to mitigate it. But we cannot eliminate identity, nor would we want to try. What we might do instead is to promote multidimensional identities rooted in the active coordination of multiple affiliations and commitments rather than the simple recognition of one's group and incorporation of its beliefs and values. This is consistent with the Eriksonian understanding that achieved identities are preferable to foreclosed identities. But we should not expect that we will eliminate genocide by making sure everyone has the right kind of identity. Indeed, as we have seen in the case of the Indian schools, efforts to shape identity may themselves turn genocidal.

To recognize that genocide is rooted in identity, then, is to recognize that the potential perpetrators of genocide include all of us, individually and in our countless collectivities. At our worst, wielding our identities, we categorize to the point of dichotomizing, stigmatize to the point of dehumanizing, and deny, even to ourselves, responsibility for destruction, past and present. At our best, we recognize and counter these processes, and we can learn to do so more consistently and effectively. But even if we could eliminate genocide from the world, the accomplishment might only be temporary. As surely as we will always form identities, the potential for genocide remains and with it the ongoing challenge to resist the forces of dichotomization, dehumanization, and denial.

\section{REFERENCES}

Adams, D. W. (1995). Education for extinction: American Indians and the boarding school experience, 1875-1928. Lawrence: University Press of Kansas.

Appiah, K. A. (2005). The ethics of identity. Princeton, NJ: Princeton University Press.

Arad, Y. (1987). Belzec, Sobibor, Treblinka: The Operation Reinhard death camps. Bloomington: Indiana University Press.

Archdiocese of Guatemala. (1999). Guatemala: Never again! Maryknoll, NY: Orbis. 
Arditti, R. (1999). Searching for life: The grandmothers of the Plaza de Mayo and the disappeared children of Argentina. Berkeley: University of California Press.

Arendt, H. (1994). Eichmann in Jerusalem: A report on the banality of evil. New York: Penguin. (Original work published 1963.)

Ashmore, R. D., Deaux, K., \& McLaughlin-Volpe, T. (2004). An organizing framework for collective identity: Articulation and significance of multidimensionality. Psychological Bulletin, 130, 80-114.

Ashmore, R. D., Jussim, L., Wilder, D., \& Heppen, J. (2001). Conclusion: Toward a social identity framework for intergroup conflict. In R. D. Ashmore, L. Jussim, \& D. Wilder (Eds.), Social identity, intergroup conflict, and conflict reduction (pp. 213-249). Oxford, UK: Oxford University Press.

Barkan, E. (2003). Genocides of indigenous peoples: Rhetoric of human rights. In G. Gellately \& B. Kiernan (Eds.), The specter of genocide: Mass murder in historical perspective (pp. 117-139). Cambridge, UK: Cambridge University Press.

Bergman, R. (2004). Identity as motivation: Toward a theory of the moral self. In D. K. Lapsley \& D. Narvaez (Eds.), Moral development, self, and identity (pp. 21-46). Mahwah, NJ: Lawrence Erlbaum.

Bouvard, M. G. (1994). Revolutionizing motherhood: The mothers of the Plaza de Mayo. Wilmington, DE: SR Books.

Brewer, M. B. (2001). Ingroup identification and intergroup conflict: When does ingroup love become outgroup hate? In R. D. Ashmore, L. Jussim, \& D. Wilder (Eds.), Social identity, intergroup conflict, and conflict reduction (pp. 17-41). Oxford, UK: Oxford University Press.

Browning, C. R. (1998). Ordinary men: Reserve Police Battalion 101 and the Final Solution in Poland. New York: HarperPerennial.

Browning, C. R. (2004). The origins of the Final Solution: The evolution of Nazi Jewish policy, September 1939-March 1942. Lincoln: University of Nebraska Press.

Chalk, F., \& Jonassohn, K. (1990). The history and sociology of genocide. New Haven, CT: Yale University Press.

Charny, I. W. (1994). Toward a generic definition of genocide. In G. J. Andreopoulos (Ed.), Genocide: Conceptual and historical dimensions (pp. 64-94). Philadelphia: University of Pennsylvania Press.

Chomsky, N. (1989). Necessary illusions: Thought control in democratic societies. Boston: South End Press.

Churchill, W. (1997). A little matter of genocide: Holocaust and denial in the Americas, 1492 to the present. San Francisco: City Lights Books.

Churchill, W. (2004). Kill the Indian, save the man: The genocidal impact of American Indian residential schools. San Francisco: City Lights Books.

Cohen, S. (2001). States of denial: Knowing about atrocities and suffering. Cambridge, UK: Polity Press.

Côté, J. (2006). Identity studies: How close are we to developing a social science of identity? Identity, 6, $3-25$.

Dallaire, R. (2003). Shake hands with the devil: The failure of humanity in Rwanda. Toronto: Random House Canada.

Danner, M. (1994). The massacre at El Mozote. New York: Vintage.

Des Forges, A. (1999). Leave none to tell the story: Genocide in Rwanda. New York: Human Rights Watch.

Fein, H. (1993). Genocide: A sociological perspective. London: Sage.

Fisher, J. (1989). Mothers of the disappeared. Boston: South End Press.

Fujii, L. A. (2004). Transforming the moral landscape: The diffusion of a genocidal norm in Rwanda. Journal of Genocide Research, 6, 99-114.

Hamblett, W. C. (2005). Guilty of innocence or nobody remembers the Armenians. Journal of Genocide Research, 7, 129-144.

Hatzfeld, J. (2005). Machete season: The killers in Rwanda speak. New York: Farrar, Straus and Giroux. 
Hulsizer, M. R., Munro, G. D., Fagerlin, A., \& Taylor, S. P. (2004). Molding the past: Biased assimilation of historical information. Journal of Applied Social Psychology, 34, 1048-1074.

Kelman, H. C. (2001). The role of national identity in conflict resolution: Experiences from Israeli-Palestinian problem-solving workshops. In R. D. Ashmore, L. Jussim, \& D. Wilder (Eds.), Social identity, intergroup conflict, and conflict reduction (pp. 187-212). Oxford, UK: Oxford University Press.

Khalidi, R. (1997). Palestinian identity: The construction of modern national consciousness. New York: Columbia University Press.

Las Casas, B. (1992). The devastation of the Indies: A brief account. Baltimore, MD: Johns Hopkins University Press. (Originally published in 1552.)

Lemkin, R. (1944). Axis rule in occupied Europe. Washington, DC: Carnegie Endowment.

Loewen, J. W. (1995). Lies my teacher told me: Everything your American history textbook got wrong. New York: Touchstone.

Lomawaima, K. T. (1994). They called it Prairie Light: The story of Chilocco Indian School. Lincoln: University of Nebraska Press.

Maalouf, A. (2001). In the name of identity: Violence and the need to belong. New York: Arcade.

Mamdani, M. (2001). When victims become killers: Colonialism, nativism, and the genocide in Rwanda. Princeton, NJ: Princeton University Press.

Maybury-Lewis, D. (2002). Genocide against indigenous peoples. In A. L. Hinton (Ed.), Annihilating difference: The anthropology of genocide (pp. 43-53). Berkeley: University of California Press.

McDonnell, M. A., \& Moses, A. D. (2005). Raphael Lemkin as historian of genocide in the Americas. Journal of Genocide Research, 7, 501-529.

Mellibovsky, M. (1997). Circle of love over death: Testimonies of the mothers of the Plaza de Mayo. Willimantic, CT: Curbstone Press.

Melvern, L. R. (2000). A people betrayed: The role of the West in Rwanda's genocide. London: Zed.

Mironko, C. (2004). Igitero: Means and motive in the Rwandan genocide. Journal of Genocide Research, 6, 47-60.

Moshman, D. (2001). Conceptual constraints on thinking about genocide. Journal of Genocide Research, 3, 431-450.

Moshman, D. (2004a). False moral identity: Self-serving denial in the maintenance of moral self-conceptions. In D. K. Lapsley \& D. Narvaez (Eds.), Moral development, self, and identity (pp. 83-109). Mahwah, NJ: Lawrence Erlbaum.

Moshman, D. (2004b). Theories of self and theories as selves: Identity in Rwanda. In C. Lightfoot, C. Lalonde, \& M. Chandler (Eds.), Changing conceptions of psychological life (pp. 183-206). Mahwah, NJ: Lawrence Erlbaum.

Moshman, D. (2005a). Adolescent psychological development: Rationality, morality, and identity (2nd ed.). Mahwah, NJ: Lawrence Erlbaum.

Moshman, D. (2005b). Genocidal hatred: Now you see it, now you don't. In R. J. Sternberg (Ed.), The psychology of hate (pp. 185-209). Washington, DC: American Psychological Association.

Moshman, D. (2006). The daughters of the Plaza de Mayo. New York: iUniverse.

Moshman, D. (in press). Conceptions of genocide and perceptions of history. In D. Stone (Ed.), The historiography of genocide. Hampshire: Palgrave Macmillan.

Osiel, M. J. (2001). Mass atrocity, ordinary evil, and Hannah Arendt: Criminal consciousness in Argentina's dirty war. New Haven, CT: Yale University Press.

Packer, G. (2002). Justice on a hill. In N. Mills \& K. Brunner (Eds.), The new killing fields: Massacre and the politics of intervention (pp. 129-153). New York: Basic Books.

Postmes, T., \& Jetten, J. (Eds.). (2006). Individuality and the group: Advances in social identity. London: Sage.

Power, S. (2002). "A problem from hell": America and the age of genocide. New York: Basic Books.

Rouse, I. (1992). The Tainos: Rise and decline of the people who greeted Columbus. New Haven, CT: Yale University Press. 
Rummel, R. J. (1994). Death by government. New Brunswick, NJ: Transaction.

Sanford, V. (2003). Buried secrets: Truth and human rights in Guatemala. New York: Palgrave Macmillan.

Sen, A. (2006). Identity and violence: The illusion of destiny. New York: Norton.

Sereny, G. (1983). Into that darkness: An examination of conscience. New York: Vintage.

Stannard, D. E. (1992). American holocaust: The conquest of the New World. Oxford, UK: Oxford University Press.

Stannard, D. E. (1998). Uniqueness as denial: The politics of genocide scholarship. In A. S. Rosenbaum (Ed.), Is the Holocaust unique? Perspectives on comparative genocide (pp. 163-208). Boulder, CO: Westview.

Stanton, G. H. (2004). Could the Rwandan genocide have been prevented? Journal of Genocide Research, 6, 211-228.

Staub, E. (1989). The roots of evil: The origins of genocide and other group violence. Cambridge, UK: Cambridge University Press.

Staub, E. (2001). Individual and group identities in genocide and mass killing. In R. D. Ashmore, L. Jussim, \& D. Wilder (Eds.), Social identity, intergroup conflict, and conflict reduction (pp. 159-184). Oxford, UK: Oxford University Press.

Staub, E. (2003). The psychology of good and evil. Cambridge, UK: Cambridge University Press.

Sternberg, R. J. (Ed.). (2005). The psychology of hate. Washington, DC: American Psychological Association.

Totten, S., Parsons, W. S., \& Hitchcock, R. K. (2002). Confronting genocide and ethnocide of indigenous peoples: An interdisciplinary approach to definition, intervention, prevention, and advocacy. In A. L. Hinton (Ed.), Annihilating difference: The anthropology of genocide (pp. 54-91). Berkeley: University of California Press.

Valentino, B. A. (2004). Final solutions: Mass killing and genocide in the 20th century. Ithaca, NY: Cornell University Press.

Waller, J. (2002). Becoming evil: How ordinary people commit genocide and mass killing. Oxford, UK: Oxford University Press.

Weitz, E. D. (2003). A century of genocide: Utopias of race and nation. Princeton, NJ: Princeton University Press.

Woolf, L. M., \& Hulsizer, M. R. (2005). Psychosocial roots of genocide: Risk, prevention, and intervention. Journal of Genocide Research, 7, 101-128. 